\title{
THE DEFENSIVE VERNACULAR SETTLEMENTS IN OMAN, A CONTEXTUAL STUDY
}

\author{
N. BENKARI \\ Department of Civil and Architectural Engineering, Sultan Qaboos University, Oman
}

\begin{abstract}
The purpose of the present research is to reveal an aspect of the defensive architecture of Oman that was overlooked for decades. It focuses on the defensive strategies in the settlements that were developed by the Omanis in most of the territories of the country. These settlements are part of the vernacular heritage and attest to the periods of conflict in the country's past. They resulted from the 'savoir-faire' developed by the Omanis in this field.

This paper argues that these strategies are not the fruit of intuitive and unthought-of gestures. Through case studies, thoroughly documented, and in comparison with other examples in the country, we show that the defensive settlements are a very specific aspect of the vernacular architecture in Oman that has been methodically developed through time due to the tumultuous history of these lands. The paper sheds the light on the typologies of defensive vernacular settlements in Oman by identifying some of their major characters, components and ways of adaptation to their geographic contexts.

Keywords: Falaj, fortified settlements, Hisn, Khandaq, Omani vernacular architecture, Qal'a, Town-wall.
\end{abstract}

\section{INTRODUCTION}

The built heritage of Oman contains numerous defensive and military buildings that spread all over the country. This rich repertoire that spans over several centuries goes from impressive constructions, such as Nizwa tower or Rustaq citadel, and elegant castles like Jabrin palace, to more complex structures like the fortress of Bahla, listed among the UNESCO world heritage sites. Some of these structures were described, studied and analysed by several researchers [1-4]. However, these buildings were approached as individual units, without much consideration to their urban and social contexts. Similarly, researchers did not focus much on the multitude of traditional settlements built by the Omanis before the modernization of the country. The researches of this topic explored it from an archaeological perspective [5-8] or adopted a combined approach of geography and archaeology [9, 10] or studied it form the point of view of the physical composition and social organization [11-14].

It is worth noting the increasing attention given to the study of the traditional settlements in Oman in the recent years. After the scattered but nonetheless valuable investigations between the 1970s and 1990s [12,13,15], the turn of the present century has witnessed more systematic and interdisciplinary researches on a certain number of the vernacular settlements in Oman. Some of these investigations were undertaken by the teams of joint research between Sultan Qaboos University and German institutions [7-10], while others were done by Nottingham Trent University and Sultan Qaboos University for the Ministry of Built Heritage of Oman $[11,16]$. Nevertheless, the defensive character of the Omani traditional

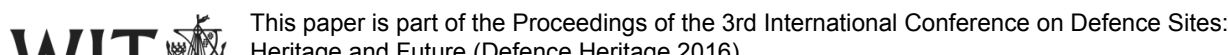
Heritage and Future (Defence Heritage 2016)

CONFERENCES www.witconferences.com
} 
settlements was only superficially evoked, if at all $[11,13,17]$, and never explored in a direct and systematic way.

This paper claims that the vernacular settlements developed by the Omanis in most of the regions of the country were affected by the topographic conditions and tribal organization of the population as well as by the tumultuous episodes it has gone through during the past half millennium. The aim of this research is to reveal the sophisticated defensive strategies which generated the unique character of these settlements and which impregnates even the civil architecture $[2,17]$. It is hoped that some light will be shed on the specific typologies of 'defensive vernacular settlements' by identifying some of their main physical characteristics and components. We claim also that this defensive character did not have similar forms or identical components in the Omani traditional settlements. Rather, the physical, social, economic and political contexts must have affected the defensive strategies that distinguish each group of settlements from the other

\section{GENERAL OVERVIEW OF THE OMANI TRADITIONAL SETTLEMENTS}

The comparative analysis of several Omani traditional settlements based on their physical layout prior to their new developments shows that these settlement could be grouped in two major groups [5]:

\subsection{The coastal zone setting (Al Batinah)}

In the coastal zone setting, the settlements are spread along the coastal strip of the country (such as Khassab, Muscat, Mutrah, Sur, Qalhat, Suhar and Zafar).

\subsection{The mountain piedmont zone setting}

The mountain piedmont zone is locally called Al-Jawf (the interior). The most common organization in this category is the oasis settlement, where peculiar climatic and terrain conditions dictated distinct settlement patterns (such as Izki, Ibra, Rustaq, Al Hamra, Mudhairib and Bahla).

The interior of Oman has always been the heart of the country and has supplied the coast of Al Batinah with grains and agricultural products. This region has also been a fertile ground for scholars and Imams who have led the country for centuries. Al Batinah, on the other hand, was always a living strip of greenery populated by prosperous communities relying essentially on trading and arts and crafts activities $[2,5]$.

The wide exposure of the country to the open seas has attracted wealth as well as invasions. In addition, the tribes of the population have also created continuous turmoil in the interiors. For centuries, the Omanis developed complex defensive strategies that culminated with the sophisticated defensive network developed during Al-Ya'ariba period (1624-1741). The interior, boarded by the desert and framed by the massive mountains, has always been linked to the coast essentially a single passage through Wadi Sama'il, which displays the most effective concentration of forts and watchtowers. The fort of Bid bid is the key to this system near the coast; Nizwa fortress is its heart [2,3]. Further to these military structures, the settlements themselves were built and organized in typologies that allowed them to serve as fortified centres for the protection of the populations as well as securing the circulation of the Imam or the sultan and his troops throughout the country's vast regions. 


\section{THE COMPONENTS OF THE DEFENSIVE SYSTEMS IN \\ THE VERNACULAR SETTLEMENTS IN OMAN}

The defensive system identified in the Omani traditional settlements is deployed in several lines or levels, starting far from the physical boundaries of the settlements and usually covering the whole territory of the tribes living in that particular settlement.

\subsection{Network of single towers (Abraj, Sing. Borj)}

A network of single towers (Abraj, Sing. Borj) in different sizes and forms is the first defensive line in the territory of the settlement (Fig. 1). It would start miles away from the actual location of the settlement. These defensive lines are usually shared by many settlements. Generally, they delineate the territories of the tribes living in the area. Most of the time, the single towers are built on top of the hills surrounding the settlements and their oases. These structures also exist within the oases to protect it and signify the limits between the properties of the different tribes sharing the cultivated lands. The single towers are basic defensive points that could host a single or a couple of guards to scrutinize the surrounding horizon. They usually work in network with other towers in the area or with the guards positioned in the settlements they are supposed to defend.

Nowadays, most of these towers have collapsed like the settlements they were protecting, because they are not used or maintained anymore. A few among them still resist the decay and it is often that the traveller through the lands of Oman would spot some of those solitary structures, punctuating the hilltops. Sometimes, these towers are the only remains of the settlements that disappeared entirely leaving behind a mound of earth and some broken woods.

\subsection{The oasis}

Based on the information collected during our investigations in several settlements, it appeared to us that the oasis had a defensive role besides its main contribution to the settlement's economy. The position of the oasis compared to the settlement depends on several

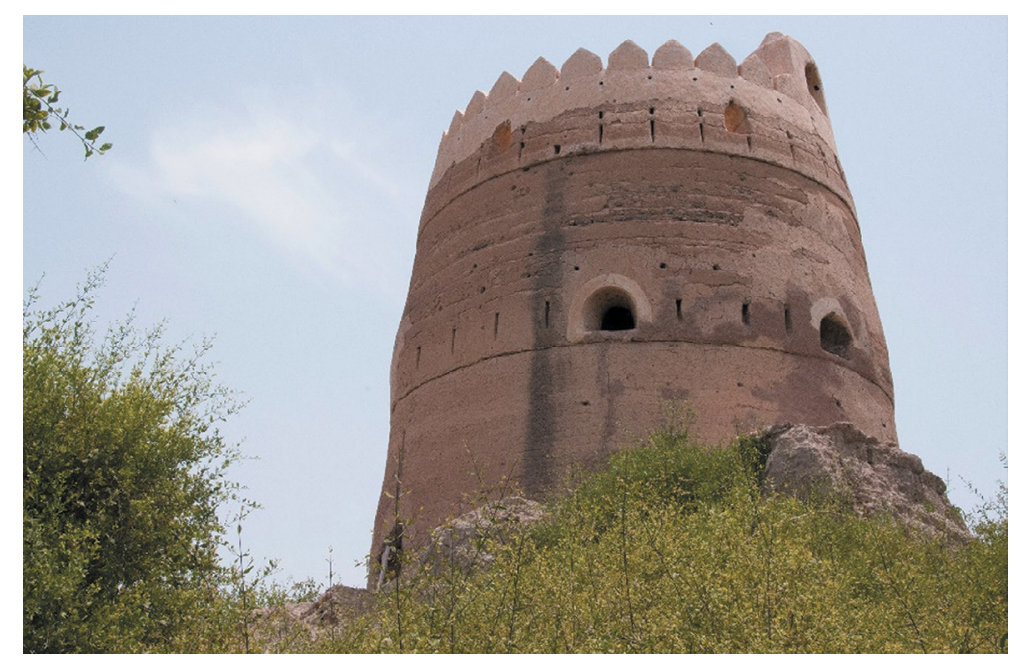

Figure 1: A watchtower in the centre of Hujrat Msalmat (Wadi Al Ma'awil). 


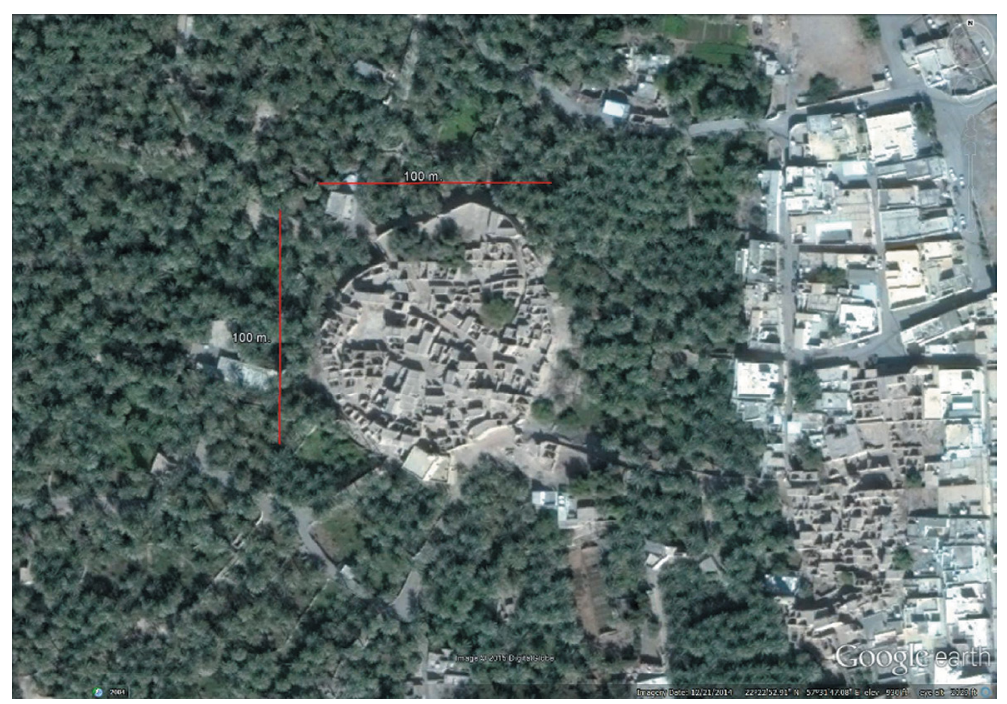

Figure 2: Harat al Hawashim in Adam surrounded with its oasis (Google map modified by the author).

factors such as the direction of the slope, the path of the sun and the source and direction of the Falaj that irrigates the land. In all observed cases, the oasis seems to have been used as a protection to the settlement. This dense green area boards the settlement or surrounds it like a belt (Fig. 2). The dense vegetation in the oasis helps greatly deal in slowing down the progress of any opponent coming from its side. Besides the forts that are usually distributed in these lands, the density of the vegetation and the height of the palms would help the guards attack the invaders with bullets or arrows from their hidden positions atop the palm trees.

Nowadays, the presence of an oasis has an important role in maintaining the surviving traditional settlements. The owners visit their deserted old dwellings while taking care of their agriculture in the oases. Some of them use these dwellings to stay during the harvest season. This habit, even seasonal, is enough to preserve the traditional houses.

\subsection{Strategic setting of a defensive settlement}

The several settlements observed showed a unique setting strategy in the site that varies following the topography and the other physical features of the site. Two major objectives governed these variable settings: protection from enemies' attacks, and securing proper irrigation for the settlement. From the point of view of the physical setting of the settlement in its site, we could distinguish two major typologies:

\subsubsection{The settlement built at the folds or on the slopes of a mountain}

In general, these settlements would be flanked against the mountain to ensure their protection and confined by the oasis from their 'exposed' lower side. The dwellings would be close to each other along the topographic contours. The buildings were arranged in reinforced terraces, and the houses located at the lowest level would have formed a continuous fortified wall protecting the interior of the settlement. It is common for such type of clusters to contain single towers punctuating their edges (Saija, Balad Set, and Misfah Al-Abriyeen) (Fig. 3). 

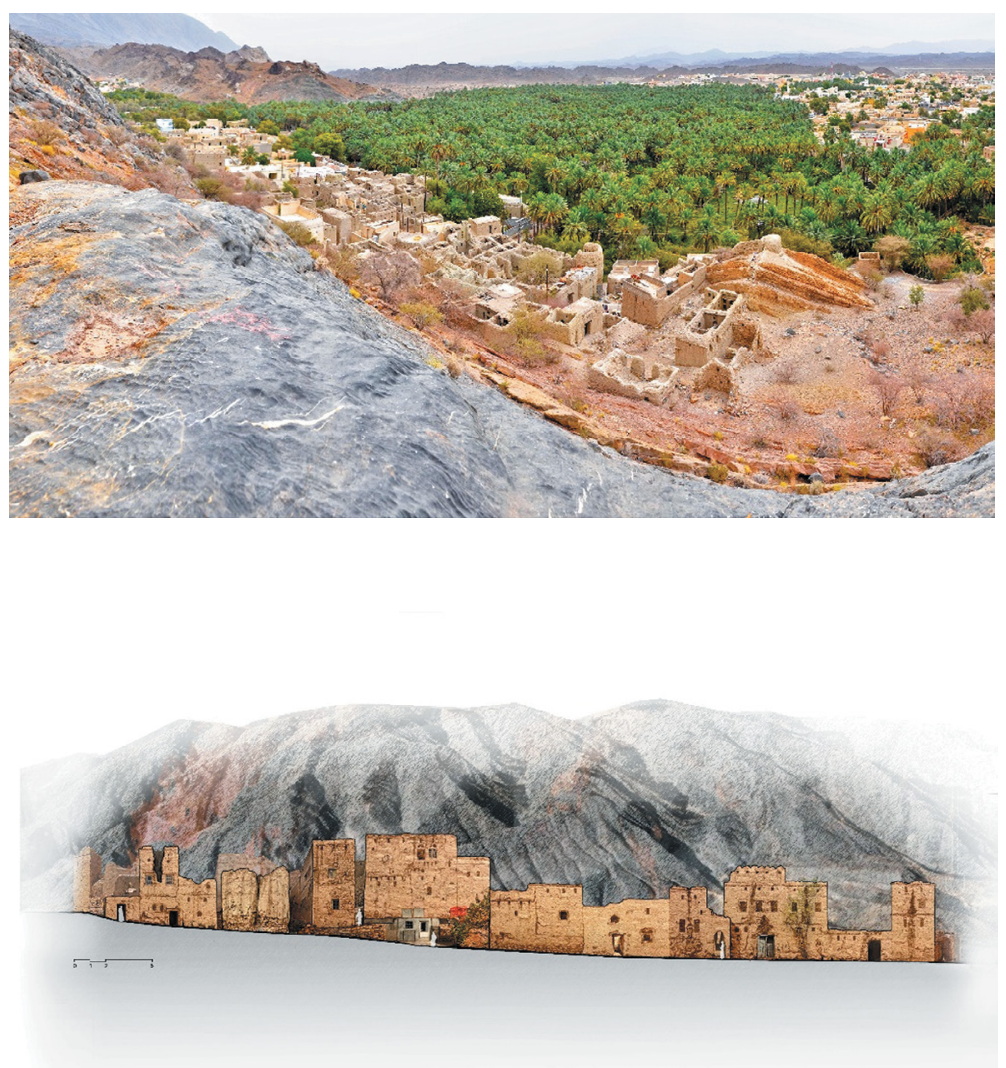

Figure 3: Harat Saija in Sama'il backed by the mountains and boarded by its oasis evolving in a longitudinal strip.

In some cases, the defensive system of such Harat (hãrãt, pl. of hãarah: quarter, district) includes forts or fortresses built by the inhabitants to secure their protection in case invaders reach their dwellings (such as Hisn 'Abs for Harat Al Khabt) [16].

\subsubsection{Settlements built on the plains}

Whether they are in the coast or in the interior (Al Jawf), at the foot of the mountains or far from them, the settlements on flat topography would be surrounded by a town wall (Sur, pl. Aswar). In some cases, this precinct is fronted by a trench (khandaq), as in the case of Sohar (Ṣuhãa) or Ḥujrat Msalmãt in Wadi Al Ma`ãwil (Fig. 4).

\subsection{The town wall (Sur) and its fortified entrances (Sabahat, sing. Sabah)}

With some very rare exceptions, all of the traditional Omani settlements, which did not have a natural setting to be confined in, were protected by town walls. Later this could be found surrounding the clusters only (like in the case of Harat Al Bilad in Manah) or including its oasis (like in the case of Harat Al 'Aqor (Nizwa) or Harat Bahla where the wall reaches $12 \mathrm{~km}$ long). The dwellings and other constructions of the settlements closest to the town wall would generally be attached to it thereby adding the thickness of their own walls to it. 


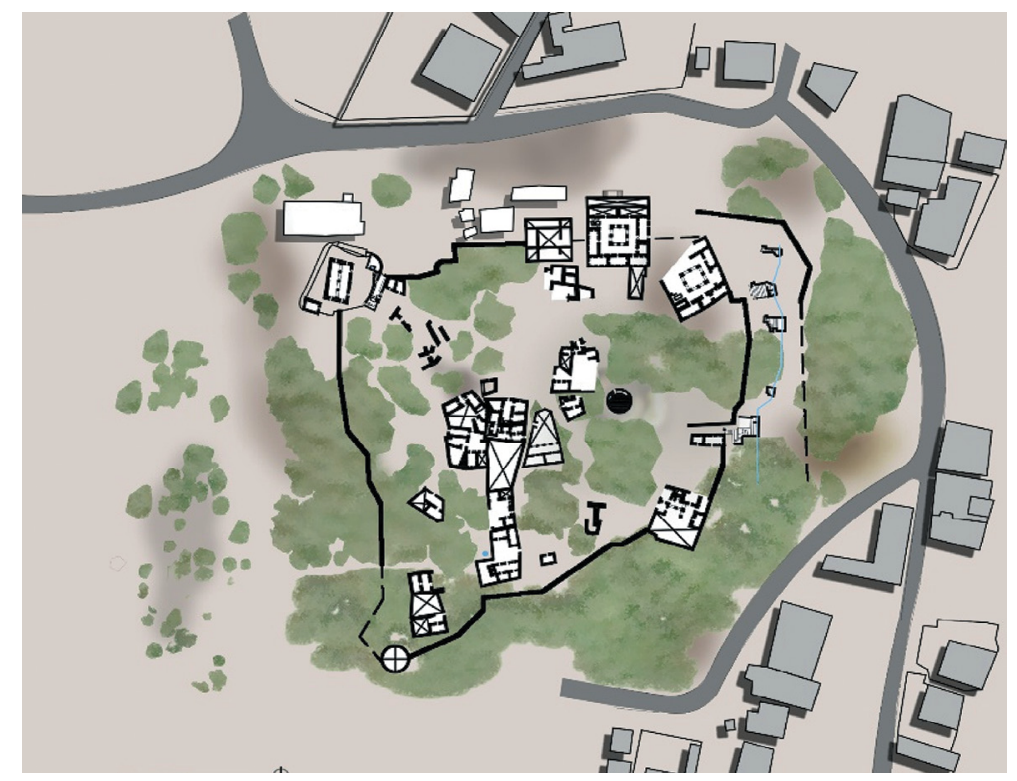

Figure 4: Layout of Hujrat Msalmat. The traces of the trench are visible through the green belt surrounding the town wall.

Whether the town wall is a standalone structure or part of the layout of the settlement's dwellings, it is always punctuated with watchtowers and equipped with loopholes and slit windows to secure the protection of the settlements.

Every settlement is open to the exterior world through a number of fortified gates (Darwaza) followed by a vaulted transition space called As-Sabah. The latter, furnished with built-in benches, used to host the settlements' guards in charge of the control of access.

\subsection{The settlements' organization}

Archaeological and architectural surveys as well as ethnologic investigations have revealed that the social organization has affected the physical layout of most of the important settlements in Oman [5, 18]. The built-up area of theses settlement is commonly organized around two cores, each of which belongs to one tribe or a congregation of allied tribes. Interestingly enough each part of the settlement has a name related to its topographic location or its position vis-á-vis the source of water: the Falaj. Most commonly one would find a 'Sufalah or Ramlah' which is the lower core and 'Alaya or Raf'a' the higher core. In between would lie the common buildings such as the sũq and the Friday mosque. In Izki, for example, one of the oldest settlements in Oman [14], there is a double composition of walled sections inhabited by tribes belonging to two congregations: Hinawi and Ghafri. The common areas such as the sũq and the Friday mosque are in between guarded by forts [5]. In Ibra, too we find two sections Alaya and Sufalah inhabited by Al Masakira and Al-Hirth respectively [5, 15]. In general, the two parties inhabiting the settlement would belong to opposed congregations (Hinawi vs. Ghafri) and sometimes internecine quarrels would erupt between the inhabitants of the same settlement, leading to large destructions and in some rare cases to the expulsion of the weakest party. In such cases, the Imam or Sultan or the Mashaikh (political and spiritual leaders) 
would intervene to find a new place to live in for the leaving party (like what was reported to us concerning the tribe of Al Hawashim (Sing Al Hashmi) of Sinaw who were forced to leave their cluster and settle in Adam, while a part of Al Mahariq (Sing. Al Mahrouqi) of Adam took their place in Sinaw). This bicephalic organization of the Omani traditional settlements is a recurrent phenomenon, however, the research in this field is far from exhaustive and therefore it is still early to speak of a systematic character. It is worth mentioning that some cases were observed in previous researches where the settlement is composed of only one tribe, for example the case of Al-Hamra. This settlement was founded around the 17th century to be inhabited by only one tribe: Al-Abriyeen [14].

Regarding the organization of buildings in the settlement itself, several strategies were applied to secure the protection of the inhabitants and their resources especially in case of war.

The common buildings where even foreigners to the settlement are expected to be admitted (Mosque, sũq and Sabla ${ }^{1}$ ) are generally located close to the fortified gates or under the protection of watchtowers. The architecture of these common buildings has a defensive character, sharing the same architectonic details as the towers, forts and citadels (crenellations, slit windows, loopholes, fortified gates, and sometimes integrating one or two towers in their massive structures, like in the Sa'al great mosque) (Fig. 5). It is worth mentioning that the houses of the settlements' leader(s) or Shaikh (pl. Shuyukh) also have this same fortified appearance. This is not only to reflect the important social position of the Shaikh but also to note that these 'Shaikhly' houses $[12,15]$ were used as citadels to protect the inhabitants and their goods during times of war.

\subsection{Secured water sources}

In Oman, all the traditional settlements have an organic relationship with their oases and the sources of their irrigation. Until the recent past, the Falaj (pl. Aflaj) was the main source of water in the settlements and the oases. The precise origin of this traditional network of water

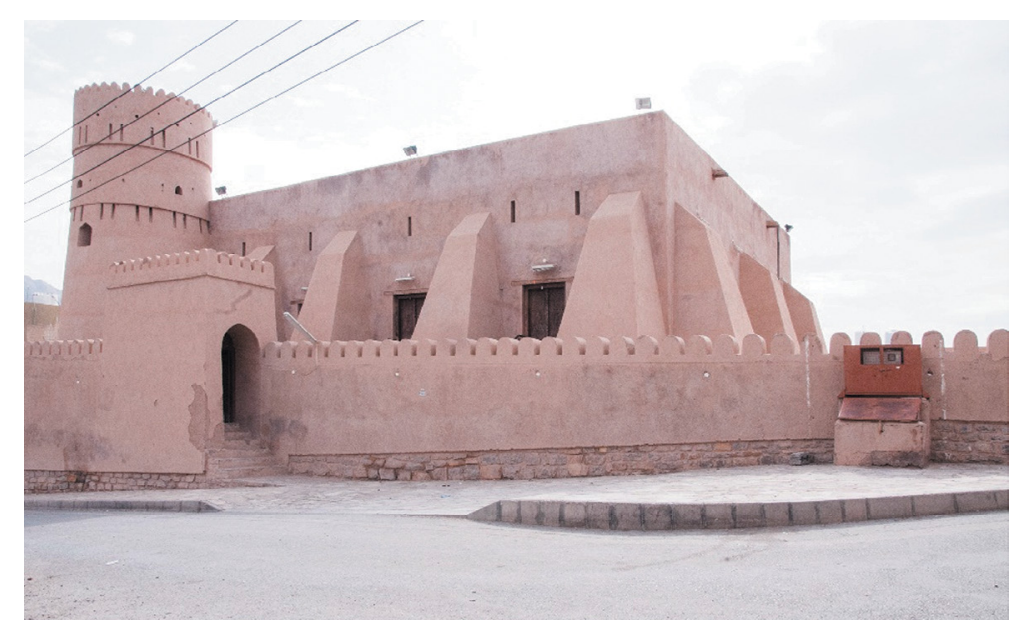

Figure 5: The picture of the great mosque of Sa'al with its tower.

1 Sabla, Pl. Sbel is a public reception and meeting hall for the community in the settlement. In general, there are as many Sbel as there are tribes or influential families in the cluster. 


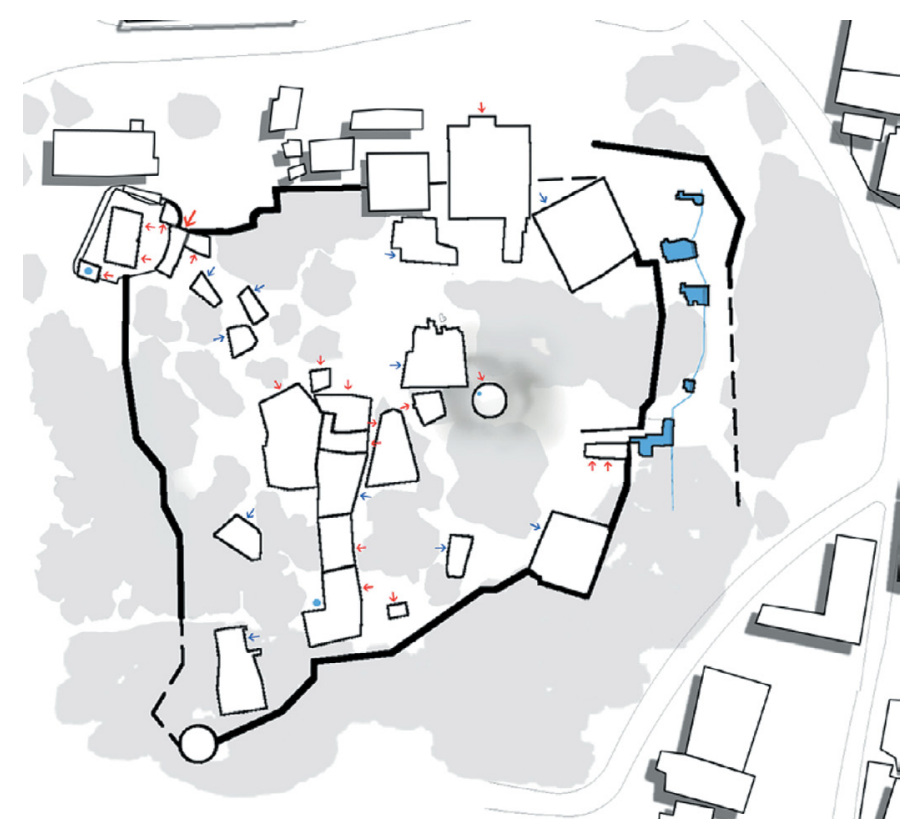

Figure 6: The Falaj of Hujrat Msalmat running outside its walls.

channels (known as Qanat in Iran) is still unknown. Nevertheless, they have existed as early as the first millennium BC with settlements connected to their paths and traces of agricultural activities around them [19]. The Falaj system in Oman has been described in several researches [20-22], but its effect on the physical layout of the traditional settlements has not been investigated enough. Because of its vital role for the subsistence of the oasis and the settlement, the Falaj was systematically used against the settlement by its enemies. They would destroy it, depriving the land and the inhabitants of water or, more rarely, they would poison the water, as it has happened in Tanuf and Sinaw.

To overcome this weakness, some settlements would possess other sources of water that could only be controlled by their inhabitants from within the settlement. Therefore, it is frequent to find wells spread over the settlements especially around the common spaces such as the mosques, Sbel, sũq, as in the case in Hujrat Msalmat or even inside dwellings, such as in Harat Qasra.

In addition to securing the water source, the Omanis developed practices to protect the falaj at the point where it reaches the settlement. It is not unusual to find portions of this channel uncovered when it is close to the town wall. This was a preventive measure to ensure that no one could use this channel to gain entry surreptitiously to the settlement. Towers would also exist close to the falaj to control it where it enters the settlement. Alternatively, like in Hujrat Msalmat, the falaj would not enter the settlement at all: instead, it is brought close to one of the fortified gates of the town so that the inhabitants may make use of its water before it runs to the oases (Fig. 6).

\section{CONCLUSION}

Based on the detailed and systematic documentation of certain Omani traditional settlements and comparisons with multiple other examples in the scientific literature, it appears that the defensive character is a specificity of the vernacular built environment in Oman. At the 
same time, this character that has been methodically developed through time impregnated the architectural language of civilian or religious structures such us the houses, Sbel (sing. Sabla) and mosques.

This research has showed that the Omani vernacular settlements present certain typologies where the defensive character is clearly pronounced and recurrent. It revealed, on the other hand, that whatever is the location of the settlement, it is adapted to its geography, and the physical specificities of its site are used to ensure its defence. The paper has also presented the major components of the Omani traditional settlements and showed how they are interconnected for securing the settlements' defence and subsistence. It has been demonstrated that there is an organic and vital relationship among the settlement, the water source (Falaj) and the oasis. Every component of this triode is essential to the two others and to the healthy growth of the whole organism.

It is perhaps a good start for more studies about the vernacular settlements in Oman in their wider settings and networks. Such researches would generate enough knowledge to rethink the way the contemporary neighbourhoods and even cities are thought and planned in the country and in the region.

\section{REFERENCES}

[1] Galdieri, E., A masterpiece of Omani 17th century architecture: The palace of Imam Bilarab Bin Sultan Al Yaariba at Jibrin. Journal of Oman Studies, 1, pp. 167-179, 1975.

[2] D'errico, E., Introduction to Omani military architecture of the 16th, 17th and 18th centuries. Journal of Omani Studies, 6(Part 2), pp. 291-306, 1983.

[3] Al-Qila' Wal-Husun Fi 'Uman, Maktab ra'is Al Wuzara' li-shu'un Majlis al wuzara', Qism A-Dirasat (Ed.), Oman, 1994.

[4] Korn, L., Fortifications and palaces (Chapter 6). Islamic Art in Oman, ed. Al-Salimi, A., Gaube, H. \& Korn, L. Muscat, 3rd edn, pp. 118-151, 2014.

[5] Costa, P.M., Notes on settlement patterns in traditional Oman. Journal of Omani Studies. 6(2), pp. 247-268, 1983.

[6] Whitcomb, D., The archeology of Oman: A preliminary discussion of the Islamic periods. Journal of Omani Studies, 1, pp. 123-157, 1975.

[7] Häser, J., Formation and transformation processes of Oasis in Sultanate of Oman: Preliminary report on a new field project. Proceedings of the Seminar for Arabian Studies, (30), pp. 115-118, 2000.

[8] Schreiber, J., Transformation processes in oasis settlements in Oman: 2005 archeological survey in Nizwa oasis, a preliminary report. Proceedings of the Seminar for Arabian Studies, (37), pp. 263-275, 2007.

[9] Nagieb, M., Siebert, S., Luedeling, E., Buerkert, A. \& Häser, J., Settlement history of a mountain oasis in Northern Oman, evidence from land-use and archeological studies. Die Erde, 135(1), pp. 81-106, 2004.

[10] Siebert, S., Häser, J., Nagieb, M., Korn, L., Buerkert, A., Agricultural, architectural and archaeological evidence for the role and ecological adaptation of a scattered mountain oasis in Oman. Journal of Arid Environments, 62, pp. 177-197, 2005. DOI: 10.1016/j. jaridenv.2004.09.023.

[11] Bandyopadhyay, S., Harat Al Bilad (Manah). Tribal pattern, settlement structure and architecture. Journal of Omani Studies, 13, pp. 183-262, 2004.

[12] Bonnenfant, P. et al., Architecture and social history at Mudayrib. Journal of Omani Studies, 3, pp. 107-135, 1977. 
[13] Mershen, B., Settlement space and architecture in South Arabian Oases - Ethnoarcheological investigations in recently abandoned settlement quarters in inner Oman. Proceedings of the Seminar for Arabian Studies, (28), pp. 201-213, 1998.

[14] Gaube, H., Settlements (Chapter 3). Islamic Art in Oman, ed. Al-Salimi, A., Gaube, H. \& Korn, L. Muscat, 3rd edn, pp. 38-59, 2014.

[15] Le Cour Grandmaison, C., Spatial organization, tribal groupings and kinship in Ibra. Journal of Omani Studies, 3, pp. 95-106, 1977.

[16] Benkari N., Documentation and management plans of Harat Qasra (Rustaq), Saija (Sama'il), Al Khabt (Khaboora) and Msalmat (Wadi Al Ma'awil). Reports submitted to the Ministry of Heritage and culture, Oman. 2016 (forthcoming).

[17] Al-Harthy, S.H., Reading the traditional built environment in Oman. Architectural education Today, ed. Salama, M.A., O'Reilly, W. \& Noschis, K. Comportements, Lausanne, pp. 125-129, 2002.

[18] Wilkinson, J.C., Water and Tribal Settlements in South-East Arabia: A Study of the Aflaj of Oman. Clarendon Press, Oxford, 1977.

[19] Boucharlat, R., Iron Age water draining galleries and the Iranian Qanat. Archeology of the United Arab Emirates. Proceedings of the First International Conference on the Archeology of UAE, eds. Potts, D., Al Naboodah, H. \& Hellyer, P., Trident Press, London, pp. 162-172, 2003.

[20] Dutton, R.W., Agriculture and the future of Falaj in Oman. BRISMES, Proceedings of the 1986 International Conference on Middle Eastern Studies, ed. Latham, J.D., Oxford, pp. 349-358, 1986.

[21] Norman, W.R., Shayya, W.H, Al-Ghafri A.S. \& McCann, I.R., Aflaj irrigation and on-farm water management in Northern Oman. Irrigation and Drainage Systems 12, pp. 35-48, 1998.

[22] Wilkinson, J.C., The organization of the Falaj irrigation system in Oman, Research Papers, School of Geography, University of Oxford, 1974. 